\title{
Supplementary cleaning does not remove protein deposits from re-usable laryngeal mask devices
}

\author{
[Le nettoyage supplémentaire n'enlève pas les dépôts de protéine sur les masques \\ laryngés réutilisables]
}

Joseph Brimacombe MB CHB FRCA MD, ${ }^{*}$ Tisha Stone MB BS, ${ }^{*}$ Christian Keller MD $\dagger$

Purpose: To test the hypothesis that supplementary cleaning facilitates removal of protein deposits from the laryngeal mask airway (LMA).

Methods: Twenty previously used Classic ${ }^{\mathrm{TM}}$ and Flexible ${ }^{\mathrm{TM}}$ LMAs were hand washed, machine washed, dried, autoclaved and then randomly allocated into four groups for supplementary cleaning. In Group A, the dorsal surface was immersed in water and the surface scrubbed with a high-speed rotating brush. In Group B, the dorsal surface was immersed in a plaque removing solution. In Group C, the dorsal surface was immersed in a protein removing solution. In Group D (controls), the dorsal surface was immersed in water. Before and after supplementary cleaning the LMAs were immersed in a protein staining solution, rinsed and a high-resolution digital image taken of the dorsal surface. The location and severity of staining were scored by two observers blinded to group assignment.

Results: Staining was similar before and after supplementary cleaning for all groups. Mild, moderate and severe staining occurred in $31 \%, 7 \%$ and $2 \%$ of zones respectively; $60 \%$ were unstained. Staining was less common on the cuff than on the backplate and distal tube (both: $P<0.00001$ ). Staining was less common on the backplate than on the distal tube $(P=0.00 \mathrm{I})$. Staining was always present on the mid-portion of the backplate or distal tube.

Conclusion: Supplementary cleaning using a rotating brush, plaque or protein removing solution does not facilitate removal of protein deposits from re-usable LMAs; however, the infectious risk associated with the protein deposits remains to be determined.

Objectif : Tester l'hypothèse selon laquelle un nettoyage supplémentaire facilite le retrait des dépôts de protéines sur les masques laryngés $(M L)$.

Méthode : Vingt ML Classic ${ }^{\mathrm{TM}}$ et Flexible ${ }^{\mathrm{TM}}$ ayant déjà servi ont été lavés à la main et à la machine, séchés, passés à l'autoclave et divisés ensuite au hasard en quatre groupes pour un nettoyage supplémentaire. Dans le Groupe A, la surface dorsale a été immergée dans l'eau et frottée avec une brosse rotative à haute vitesse. Dans le Groupe B, la surface dorsale a été immergée dans une solution pour l'élimination de la plaque. Dans le Groupe C, la surface dorsale a été immergée dans une solution pour l'élimination des protéines. Dans le Groupe D (témoins), la surface dorsale a été immergée dans l'eau. Avant et après le nettoyage supplémentaire, les ML ont été immergés dans une solution pour colorer les protéines, puis rincés et une image digitale à haute résolution de la surface dorsale a été prise. La localisation et la sévérité des taches ont été cotées par deux observateurs impartiaux.

Résultats : Les taches étaient similaires avant et après le nettoyage supplémentaire dans tous les groupes. Des taches légères, moyennes et importantes ont été noté dans $31 \%, 7 \%$ et $2 \%$ des zones respectivement; $60 \%$ ne portaient pas de taches. Les taches étaient plus rares sur le ballonnet que sur la partie dorsale et le tube distal (pour les deux : $P<0,00001$ ). Les taches étaient moins fréquentes sur la partie dorsale que sur le tube distal $(P=0,001)$. Des taches étaient toujours présentes sur la portion médiane de la partie dorsale ou du tube distal.

Conclusion : Le nettoyage supplémentaire avec une brosse rotative, une solution pour l'élimination de la plaque ou des protéines ne facilite pas le retrait des dépôts de protéines sur les $M L$ réutilisables; cependant, le risque d'infection n'a pas été déterminé.

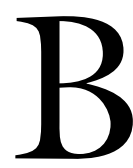

OVINE spongiform encephalopathy appeared in British cattle in 1986, and was recognized in humans in 1996 having crossed the species barrier. ${ }^{1}$ It is caused by an infectious prion protein ${ }^{2}$ that is highly resistant to decontamination by routine cleaning and autoclaving

From the Departments of Anaesthesia and Intensive Care, Cairns Base Hospital, ${ }^{*}$ Cairns, Australia; and the Leopold-Franzens University, $\dagger$ Innsbruck, Austria.

Address correspondence to: Prof. J. Brimacombe, Department of Anaesthesia and Intensive Care, Cairns Base Hospital, The Esplanade, Cairns 4870, Australia. E-mail: jbrimaco@bigpond.net.au

Disclosure: This project was supported solely by departmental resources.

Accepted for publication July 8, 2003.

Revision accepted November 28, 2003. 
procedures. ${ }^{1,3}$ Though little is known about the risk of cross-infection from re-usable surgical and anesthesia equipment, it has been suggested that all surgical patients are screened for prion disease, or all equipment made disposable $;^{4,5}$ however, the economic consequences of these options are considerable. One of the most common re-usable items of anesthesia equipment is the laryngeal mask airway (LMA). Miller et $a l .{ }^{4}$ showed that: 1) hand washing with detergent and autoclaving does not remove all protein contamination from re-usable LMA devices; and 2) most staining occurs on the dorsal surface of the cuff portion. We test the hypothesis that supplementary cleaning facilitates removal of protein deposits from the LMA. We also determine the distribution of protein deposits on the dorsal surface of the cuff.

\section{Methods}

Twenty previously used Classic ${ }^{\mathrm{TM}}$ and Flexible ${ }^{\mathrm{TM}}$ LMAs (Laryngeal Mask Company, Henley-on-Thames, UK) were tested at the end of a working day (greater than ten uses; pre-use check tests passed). ${ }^{6}$ Each LMA was cleaned and sterilized as follows: 1) immersion in a mild enzymatic solution (Enzyme Rapid, 3M, Pymble, Australia) for three minutes; 2) washing the external surfaces with a cloth for at least one minute or until all visible material was removed; 3 ) washing the airway tube with a soft bristled brush or until all visible material was removed; 4) placing the LMA in an automatic washer for 14 min which included warm washing at $55^{\circ} \mathrm{C}$ with a disinfectant and hot washing at $85^{\circ} \mathrm{C}$; 5) placing in a dryer for $30 \mathrm{~min}$ at $75^{\circ} \mathrm{C}$; and 6) autoclaving at $134^{\circ} \mathrm{C}$ for four minutes at $206 \mathrm{kPa}$.

The LMAs were randomly allocated (by opening an opaque envelope) into four equal-sized groups for supplementary cleaning. In Group A, the dorsal surface was immersed in water and the surface scrubbed with a high-speed, $1-\mathrm{cm}$ wide rotating brush for two minutes (3D pulsating toothbrush 4729, Braun, Germany). In Group B, the dorsal surface was immersed in a plaque removing solution for $30 \mathrm{~min}$ (Plax Fresh Mouthwash, Colgate Oral Care, Sydney, Australia). In Group C, the dorsal surface was immersed in a protein removing solution for five hours (subtilisin $0.01 \mathrm{mg} \cdot \mathrm{mL}^{-1}$ AMO Complete Protein Remover, Advanced Medical Optics, Sydney, Australia). In Group D (controls), the dorsal surface was immersed in water for five hours. Before and after supplementary cleaning the LMAs were immersed for $30 \mathrm{~min}$ in a protein staining solution $(1.2 \%$ erythrosin B), ${ }^{7}$ rinsed in water at $20^{\circ} \mathrm{C}$ for one minute and a high resolution digital image ( 3.3 megapixels) taken of the dorsal surface. The images were analyzed by dividing

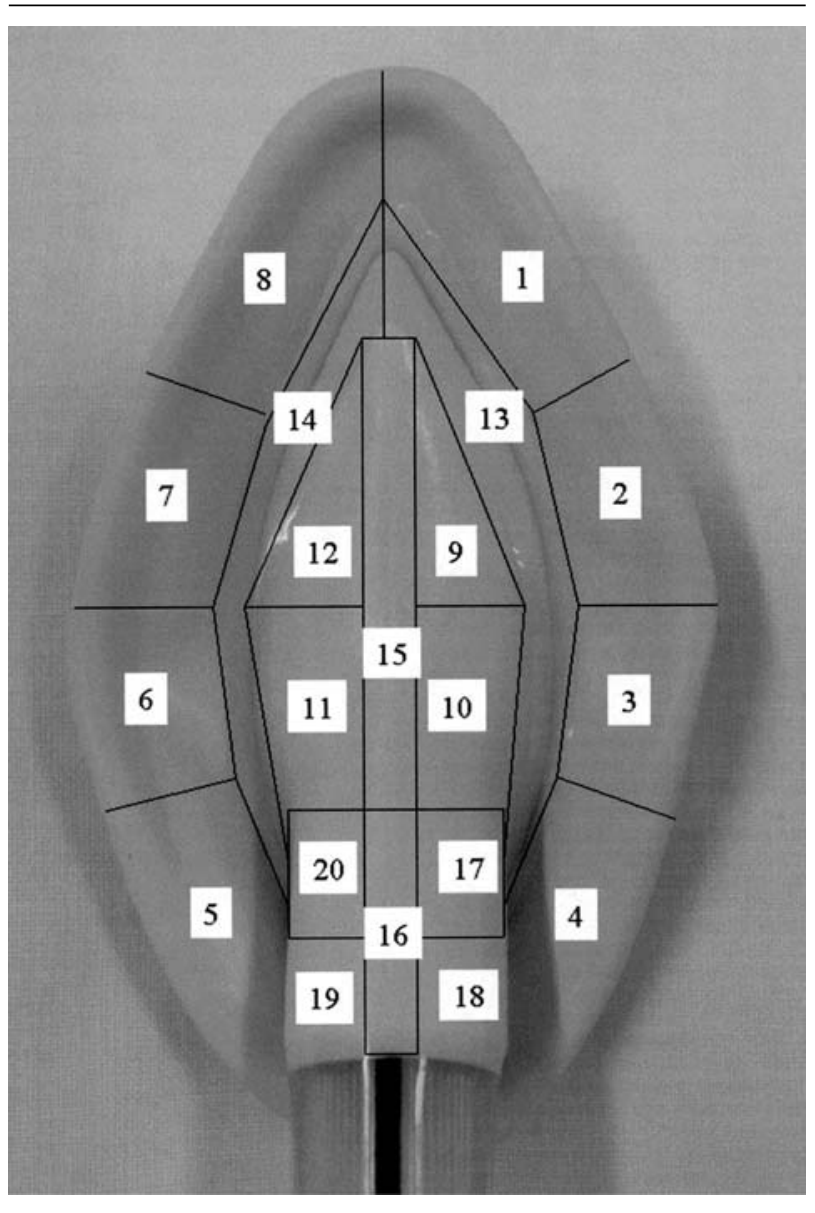

FIGURE 1 Zones on the dorsal portion of the cuff.

the dorsal surface into 20 zones (Figure 1) and scoring the severity of staining in each zone according to the percentage of area stained: 0 (nil), l (mild, $\leq$ $10 \%$ ), 2 (moderate, $>10 \%-50 \%$ ) and 3 (severe, > $50 \%)$. The overall staining score was determined by adding the staining scores from the 20 zones (maximum score 60 ). The images were analyzed by two observers blinded to the timing of the staining and the type of supplementary cleaning, and the average taken. Another three previously used LMAs (history as above) were collected, stained, cleaned with the protein removing solution, restained and photographed as above, but were also photographed just before the second staining. Sample size was selected for a type I error of 0.05 and a power of 0.85 with four groups and was based on a pilot study with four LMAs with an effect size of 0.644. Statistical analysis was with Chi squared test. 


\section{Results}

There were no differences in scoring among observers. Staining was similar before and after supplementary cleaning for all groups (Table I). The mean (range) overall staining score was 10 (3-27). Mild, moderate and severe staining occurred in $31 \%$, $7 \%$ and $2 \%$ of zones respectively; $60 \%$ of zones were unstained. Staining was less common on the cuff than the backplate and distal tube (both: $P<0.00001$; Table II). Staining was less common on the backplate than the distal tube $(P=0.001$; Table II). Staining was more common on the mid-portion of the backplate $(P$ $=0.002)$ and distal tube $(P=0.003)$ than any other

TABLE I Overall staining score before and after supplementary cleaning

\begin{tabular}{llc}
\hline & $\begin{array}{c}\text { Before } \\
\text { nil/mild/moderate/severe }\end{array}$ \\
\hline Control & $65 / 27 / 7 / 1$ & $65 / 27 / 7 / 1$ \\
Brush & $50 / 38 / 9 / 3$ & $50 / 38 / 9 / 3$ \\
Plaque remover & $60 / 32 / 5 / 3$ & $60 / 32 / 5 / 3$ \\
Protein remover & $64 / 29 / 6 / 1$ & $64 / 29 / 6 / 1$ \\
\hline
\end{tabular}

Data are numbers. No significant differences.

TABLE II Severity of staining by location

\begin{tabular}{|c|c|c|c|c|}
\hline & Nil & Mild & Moderate & Severe \\
\hline \multicolumn{5}{|l|}{ Cuff } \\
\hline 1 & 18 & 2 & 0 & 0 \\
\hline 2 & 11 & 9 & 0 & 0 \\
\hline 3 & 17 & 3 & 0 & 0 \\
\hline 4 & 15 & 5 & 0 & 0 \\
\hline 5 & 17 & 3 & 0 & 0 \\
\hline 6 & 17 & 3 & 0 & 0 \\
\hline 7 & 17 & 3 & 0 & 0 \\
\hline 8 & 16 & 4 & 0 & 0 \\
\hline Subtotal & $128(80)$ & $32(20)$ & $0(0)$ & $0(0)$ \\
\hline \multicolumn{5}{|l|}{ Backplate } \\
\hline 9 & 8 & 11 & 1 & 0 \\
\hline 10 & 14 & 6 & 0 & 0 \\
\hline 11 & 10 & 9 & 1 & 0 \\
\hline 12 & 11 & 7 & 2 & 0 \\
\hline 13 & 11 & 9 & 0 & 0 \\
\hline 14 & 14 & 6 & 0 & 0 \\
\hline 15 & 2 & 10 & 6 & 2 \\
\hline Subtotal & $70(50)$ & $58(41)$ & $10(7)$ & $2(2)$ \\
\hline \multicolumn{5}{|l|}{ Distal tube } \\
\hline 16 & 1 & 5 & 9 & 5 \\
\hline 17 & 13 & 7 & 0 & 0 \\
\hline 18 & 11 & 8 & 1 & 0 \\
\hline 19 & 5 & 10 & 4 & 1 \\
\hline 20 & 11 & 6 & 3 & 0 \\
\hline Subtotal & $41(41)$ & $36(36)$ & 17 (17) & $6(6)$ \\
\hline Total & $239(60)$ & $126(31)$ & $27(7)$ & $8(2)$ \\
\hline
\end{tabular}

Data are numbers $(\%)$.

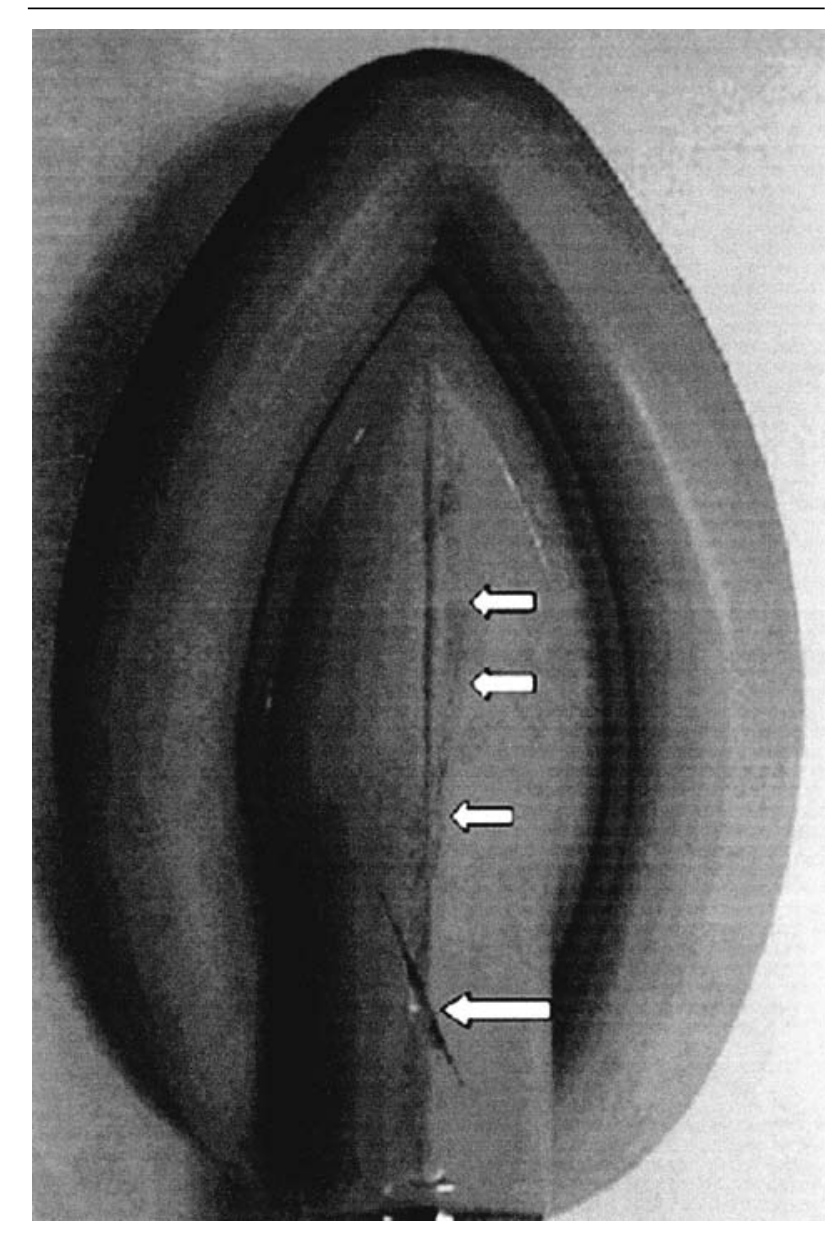

FIGURE 2 Typical staining of the mid-portion of the backplate and distal cuff (short arrows). There is also a stained abrasion (long arrow).

zone (Table II). All devices had staining on the midportion of the backplate or distal tube. On three devices linear abrasions showed up as areas of severe staining (Figure 2). The three additional LMAs cleaned in the protein removing solution showed that supplementary cleaning removed most of the first stain (median score 16 vs 4), but this reappeared with the same distribution and severity after the second stain (median score 16).

\section{Discussion}

We found that supplementary cleaning using a rotating brush, plaque or protein removing solution does not facilitate removal of protein deposits from the reusable LMA. This suggests that proteins, once attached, are highly adherent to the surface of the 
LMA. Options for increasing the efficacy of protein removal include: 1) increasing the abrasiveness, speed and/or duration of brushing; 2) using different and/or stronger solutions for a greater duration; and 3 ) increasing the temperature and/or duration of autoclaving. However, all these techniques run the risk of damaging the device. Another option might be to modify the sequence of cleaning.

We found that protein staining was more common on the backplate and distal tube than the cuff. This may be related to their surfaces being more irregular at a microscopic level or due to increased exposure to protein contamination. Interestingly, we found that staining occurred most commonly on the mid-portion of the backplate and distal tube. This is the surface that is pressed most firmly into the mucosa during insertion. We speculate that transient high mucosal pressures combined with shearing forces during insertion increase the level of protein contamination in this area. The presence of severe staining on three linear abrasions indicates the ease with which protein can collect on irregular surfaces.

We found protein deposits on all LMAs before supplementary cleaning confirming Miller et al.'s ${ }^{4}$ finding that conventional cleaning and autoclaving does not remove all protein deposits; however, our level of contamination may have been lower since moderate and severe staining occurred in less than $10 \%$ of zones, whereas Miller $e t$ al. ${ }^{4}$ graded $45 \%$ of LMAs as moderately or heavily stained. Our finding that supplementary cleaning removed most of the first stain, but not the underlying protein, as indicated by its reappearance with the second stain, suggests that the first stain did not protect the protein from removal.

The risk of prion disease transmission from re-usable LMAs is unknown. Although the frequency of prion disease is around one per million ${ }^{3}$ and the number of LMA uses is around 20 million per annum, an accurate estimate of risk cannot be determined since there are no data about the frequency of LMA contamination from an infected patient, no data about the infective dose, and no data about the amount of contaminant removed or denatured with each use/cleaning/autoclave cycle. There are no reports of prion or other infections from re-usable LMAs, but prion transmission via blood ${ }^{8}$ and oral inoculation ${ }^{9}$ has been reported in animal models.

We conclude that the supplementary cleaning using a rotating brush, plaque or protein removing solution does not facilitate removal of protein deposits from reusable LMAs. The mid-portion of the backplate and distal tube is the most heavily stained area on the dorsal surface of the cuff. The infectious risk associated with such protein deposits remains to be determined.

\section{References}

1 Will RG, Ironside JW, Zeidler $M$, et al. A new variant of Creutzfeldt-Jacob disease in the UK. Lancet 1996; 347: 921-5.

2 Haltia M. Human prion diseases. Ann Med 2000; 32: 493-500.

3 Hilton DA. ${ }_{\mathrm{V}} \mathrm{CJD}-$ predicting the future? Neuropathol Appl Neurobiol 2000; 26: 405-7.

4 Miller DM, Youkhana I, Karunaratne WU, Pearce A. Presence of protein deposits on 'cleaned' re-usable anaesthetic equipment. Anaesthesia 2001; 56:

1069-72.

5 Smith G. Variant CJD; what you need to know at present. The Royal College of Anaesthetists Bulletin 2001; 7: 302-4.

6 Verghese C. LMA-Classic ${ }^{\mathrm{TM}}$, LMA-Flexible ${ }^{\mathrm{TM}}$, LMAUnique $^{\mathrm{TM}}$. Instruction Manual. Henley-on-Thames: The Laryngeal Mask Company Ltd; 1999.

7 Leknes KN, Lie T. Erythrosin staining in clinical disclosure of plaque. Quintessence Int 1988; 19: 199-204.

8 Hunter N, Foster J, Chong M, et al. Transmission of prion disease by blood transfusion. J Gen Virol 2002; 83: 2897-905.

9 Bartz JC, Kincaid AE, Bessen RA. Rapid prion neuroinvasion following tongue infection. J Virol 2003; 77: 583-91. 